\title{
Trajetórias escolares de jovens assentados: estudo em Arinos/MG
}

\author{
Elza Carneiro Batista' \\ Marcia da Silva Mazon ${ }^{2}$
}

\section{Resumo}

Este artigo aborda as trajetórias escolares de jovens de dez famílias de assentamentos da Reforma Agrária no município de Arinos/MG. Situado na mancha de assentamentos do Entorno do Distrito Federal, este município foi cenário de manifestações de luta pela terra como também pela educação dos assentados. Na esteira de estudos recentes e partindo dos autores Pierre Bourdieu e Bernard Lahire, o objetivo foi investigar a relação entre dinâmica familiar e trajetória escolar de alunos das famílias pesquisadas e que são atendidos pelo IFNMG e pela Escola Estadual Chico Mendes. Constata-se que as famílias constroem uma perspectiva escolar para os filhos ao mesmo tempo em que lutam pelo direto à educação. Longe dos dispositivos do capital cultural acionadores do sucesso escolar, os pais atuam liberando os filhos do trabalho doméstico e da roça e, também, incentivando a continuação dos estudos. Estes foram elementos destacados nas entrevistas e que surgem como motivadores da permanência ou retorno aos estudos distinguindo-se de outras pesquisas com famílias de baixa renda.

Palavras-chave: Família. Sistema escolar. Assentamentos de reforma agrária. Capital cultural.

\section{Introdução}

Propomo-nos a analisar, neste artigo, a experiência de jovens assentados no acesso à educação. Investigamos a dinâmica familiar e a trajetória escolar de alunos provenientes de famílias de assentados da reforma agrária e seu contato com a escola do assentamento Chico Mendes táo bem como o contato com o Instituto Federal do Norte de Minas Gerais (IFNMG), em Arinos. $\mathrm{O}$ estudo de trajetórias escolares vem ganhando novos contornos. Um dos temas das novas pesquisas são a natureza e o grau de investimento familiar na vida escolar dos filhos. Igualmente, pesquisas recentes apontam uma da

I Mestre em sociologia política pelo PPGSP/UFSC; pedagoga do IFNMG/Arinos,E-mail: elza.carneiro@ifnmg.edu.br. A autora agradece o IFNMG que, por meio do Programa de Qualificação de Servidores, concedeu a bolsa que tornou possivel a realização desta pesquisa.

2 Doutora em Sociologia Política pelo PPGSP/UFSC. Docente do Departamento de Sociologia e Ciência Política e do PPCSP/UFSC. Coordenadora do Núcleo de Sociologia Econômica (NUSEC). E-mail: marcia.mazon@ufsc.br 
contribuição de famílias de baixa renda para a construção de uma trajetória escolar bem-sucedida dos filhos mesmo em face da ausência de capital escolar e material (PORTES, 2011). Zago (2011) e Viana (2011) também consideram essa mobilização da família como elemento-chave no desempenho escolar dos filhos. Nesse sentido, esta pesquisa pretende contribuir para o entendimento de alguns aspectos da relação das famílias dos assentados com o destino escolar dos filhos.

Carneiro (1998) afirma que existe um estereótipo dos jovens rurais, já que eles são apontados nas pesquisas sempre sob a ótica do trabalho, como um aprendiz de agricultor ou como um trabalhador que complementa a renda da família. Este artigo propóe uma reflexão sobre a juventude rural no intuito de retirá-la de sua invisibilidade no que diz respeito às outras esferas, sobretudo a educacional.

O foco deste artigo foram os estudantes filhos de famílias assentadas que estáo cursando o Ensino Médio no IFNMG ou que passaram por ele no período escolar e, ainda, aqueles que estudam ou estudaram na escola do assentamento Chico Mendes. A pesquisa foi realizada com as famílias dos assentamentos Roça, Carro Quebrado, Chico Mendes e Carlos Lamarca todos no município de Arinos/MG. O assentamento Chico Mendes, o maior deles com 136 famílias, abriga uma escola de Ensino Fundamental e Médio33.

Analisamos as trajetórias dos alunos tomando como referência Pierre Bourdieu e Bernard Lahire. Bourdieu (2013 d, p. 73) alerta para a necessidade de avaliar investimentos que vão além dos investimentos financeiros na educação dos filhos, considerando que o mais oculto e determinante socialmente é a transmissáo doméstica do capital cultural ${ }^{4}$. $\mathrm{O}$ autor também destaca como característica potencial do capital cultural o "tempo" durante o qual determinado indivíduo pode prolongar seu empreendimento de aquisiçáo, fato que depende do tempo livre que sua família pode lhe assegurar (p. 76).

Em contrapartida, Lahire (2008) propóe que se estude o sucesso da escolarização das camadas populares não como exceçáo à regra, mas como objeto

3 Os dados sobre o ano de criação dos assentamentos, respectivas portarias e distância em relação ao município de Arinos estão disponiveis na tabela do Anexo I.

4 Bourdieu (2013d) mostra que o capital cultural pode existir sob três formas: incorporado, objetivado e institucionalizado. A parte mais importante da herança cultural (cultura livre ou língua) se transmite de maneira osmótica, involuntária, o que reforça nos membros das classes cultas a ideia do "dom", distante da aprendizagem. 
em si. Criticando os trabalhos que mobilizam dados estatísticos puros sobre as classes populares - os quais enfatizam exclusivamente dados posicionais (renda, profissáo do pai, local de moradia) -, a proposta desse autor é pensar relacionalmente sucesso e fracasso escolar inspirado no conceito de configuraçáo social de Elias; assim, aborda tanto as configuraçóes como os perfis familiares pensando família e escola enquanto redes de interdependência. $\mathrm{O}$ autor analisa as formas familiares de cultura escrita, ordem moral doméstica e os modos familiares de investimento pedagógico.

Além disso, Lahire (2001) critica ao mesmo tempo em que dá continuidade à obra de Bourdieu. Ele observa que diferenças interindividuais são um produto das relaçóes sociais; todavia, o social não se reduz às relaçóes sociais, os indivíduos são aquilo que suas múltiplas experiências fazem deles. Propondo uma sociologia psicológica que se interessa pelo sujeito empírico, Lahire convida a uma visão mais complexa do indivíduo: menos unificado e portador de habitus heterogêneos, contraditórios 5 . Lahire critica Bourdieu, entre outros, pelo fato de não explicitarem o próprio processo de construção, inculcação, transmissão das disposiçôes, visto que as "[...] disposiçôes são deduzidas das práticas sociais, porém, não explicadas" (LAHIRE, 2001, p. 128). Para esse autor, o conceito tem de ultrapassar sua única invocaçáo ritual de simples passado incorporado tomando por objeto a construção e o modo de vida desse passado ${ }^{6}$ (LAHIRE, 2001, p. 129).

No caso brasileiro, Zago (2011) toma estes dois autores como referência para entender os processos de escolarização em famílias de baixo poder aquisitivo, e sugere que sejam empregadas estratégias educativas diversas, entre outras práticas familiares. Alves et al. (2013) observam como, na vida doméstica, os genitores - especialmente as mães - valem-se de seu patrimônio de conhecimentos na organizaçáo de um apoio pedagógico permanente que dá suporte, complementa e amplia a açáo cognitiva da escola. Neste artigo,

5 Lahire (200I) propõe estudar o social individualizado, o que significa refratado dentro de um corpo individual, tendo a particularidade de atravessar instituições, grupos, cenas, campos de força e lutas diferentes.

6 Lahire (200 I, p. 136) questiona, igualmente, o caráter de transferabilidade das disposições socialmente constituidas tão bem como a generalização abusiva (a ideia de que todas as disposições seriam em todas as ocasiões transferíveis e generalizáveis). Tentando escapar de uma visão homogeneizadora, propõe pensar um singular plural do individuo em sociedade e responder como distribui sua energia e seu tempo em diferentes universos; o tempo finito investido em um domínio profissional não será investido no tempo doméstico, por exemplo. 
trazemos os dados das famílias e os associamos aos dados posicionais de renda e escolaridade, a liberação do trabalho doméstico ou na terra, para entender a forma como se realiza a conciliação entre ser assentado e estudante. Viana (2011), seguindo Lahire, destaca como característica da longevidade escolar em camadas populares a heterogeneidade de configuraçóes familiares e mostra que a autodeterminação é construída no próprio processo de escolarização e não tem existência a priori (VIANA, 2011, p. 52). Ainda Van Zanten (2010) investiga as escolhas escolares de pais de classe média na França separando-os em dois grupos ideal típicos, o primeiro com maior capital econômico e mais segregacionista nas escolhas e o segundo com maior acento de capital cultural e menos segregacionista ${ }^{7}$. Dessa forma, veremos que a experiência de sentir-se segregado é uma constante na trajetória dos estudantes assentados.

Dados da Pesquisa Nacional da Reforma Agrária (PNERA) (BRASIL, 2005) indicavam que para $15,46 \%$ dos jovens rurais o acesso à unidade escolar estava entre os maiores problemas (longa distância, estradas de chão, falta de transporte) (BRASIL, 2005). Além disso, Leite et al. (2004) destaca que a distância da escola é motivo para que $31 \%$ das crianças e jovens abandonem a escola.

Durante a pesquisa, analisamos o modo como as famílias envolvidas no processo de reforma agrária, sobretudo jovens em idade escolar, vivenciam a experiência de serem assentados e constroem sua relação com a educação formal. Nesse sentido, este artigo visa a responder como a condição de assentado marca as escolhas e trajetórias destes jovens em relação à escolaridade e à participação da família nesse processo.

Pesquisando os cursos técnicos integrados do IFNMG (entre 2010 e 2012) foi possível constatar um total de 267 alunos matriculados em dez turmas. Destes, inicialmente, 17 eram assentados. Conversando com professores (e outros informantes), chegamos a um total 23 alunos, dos quais 11

7 Van Zanten (2010, p. 410) questiona a suposição que exista um "ethos segregativo" prévio de certos grupos sociais, e segue as pistas de autores como Granovetter para dar destaque ao contexto no qual a segregação toma forma. Essa autora propõe pensar as operações mentais e práticas que levam pais de classe média a enxergarem certos grupos como diferentes de si. 
são participantes desta pesquisa. Conhecemos 10 famílias de 11 alunos (dois deles irmáos) $)^{8}$.

Dos náo entrevistados, um foi para o exército, o segundo mudou-se para Goiás (onde conseguiu emprego em sua área de formação - técnico em agropecuária), e a terceira aluna igualmente mudou-se para Goiás após seu casamento. Ainda fizeram parte desta pesquisa: duas alunas egressas do IFNMG - campi Arinos. A primeira fez o curso técnico na modalidade subsequente e a segunda na modalidade concomitante (esta hoje é acadêmica de um curso superior de tecnologia do IFNMG). Igualmente, participaram dois alunos que hoje estudam na Escola Estadual Chico Mendes, depois de terem desistido do IFNMG.

Quatro alunos nunca foram reprovados (embora dois tenham optado por repetir algumas séries) e nove foram reprovados pelo menos uma vez no Ensino Fundamental ou Médio. Nove desses 13 alunos recebem/receberam assistência estudantil ou são bolsistas de iniciação científica (quatro alunos, inclusive, acumulam os dois benefícios) ${ }^{9}$ ver o Anexo2.

Este artigo está dividido em três seções. Na primeira, analisamos o histórico da regiáo e a constituição dos assentamentos. $\mathrm{Na}$ segunda, apresentamos os assentamentos e a história da luta por uma escola. Na ultima seção, articulamos os temas da educaçáo, desigualdade e trajetória dos jovens a partir dos dados das entrevistas ${ }^{10}$ com as famílias dos assentados e as experiências escolares dos filhos.

\section{Aspectos históricos da região, dos assentamentos e a demanda por uma escola}

A criação de Brasília, na década de 1950, promoveu a drástica alteração dos eixos de migração interna, (antes do Norte/Nordeste para o Sudeste) situando a nova capital federal como uns dos principais centros de atração de migrantes do país.

8 Os outros 10 alunos são oriundos de assentamentos de outros municipios (Uruana de Minas, Urucuia, Unaí, Buritis) que não fizeram parte desta pesquisa. A amostra da pesquisa foi composta por 37 entrevistas, sendo 13 alunos, nove pais de alunos, quatro professores, três políticos, cinco assentados ligados ao MST e três assentados não vinculados ao MST. Ver o Anexo 2.

9 Vero Anexo 2.

10 Todos os trechos das narrativas ilustram a resposta expressa pelos entrevistados; por isso, foram mantidos os desvios à norma padrão culta. 
O mundo de oportunidades simbolicamente representado por Brasília significou a constituição de um verdadeiro cinturão de problemas para os pequenos municípios adjacentes. Assim, a região do Entorno do Distrito Federal passou a conviver com um paradoxo que associa a modernidade representada por Brasília ao atraso dos latifúndios improdutivos e da pecuária extensiva. (LEITE et al.., 2004, p. 49-50).

Os conflitos entre posseiros e grileiros de um lado, colonos e proprietários do outro, somados à presença de trabalhadores rurais sem-terra e sem trabalho nas áreas periféricas das cidades da regiấo, deram origem a um "cenário político-social favorável à reforma agrária", sobretudo com a presença e a atuação da Igreja Católica, do movimento sindical e de instituiçóes como FETAEMG, FETAEG, CUT e MST (LEITE et al., 2004, p. 50). O marco referencial na luta pela terra foi a desapropriação das fazendas Saco Grande/Palmeirinha (em Unaí, 1984) e Fruta DıAnta (em João Pinheiro, 1986). Essa desapropriação impulsionou novas lutas, criando nessa região a chamada Mancha do Entorno do Distrito Federal, a qual possui 57 assentamentos da reforma agrária (LEITE et al., 2004).

O Ministério do Desenvolvimento Agrário indica, que existem no Noroeste de Minas 79 assentamentos, abarcando 5.715 famílias, mais treze acampamentos com aproximadamente 863 famílias (BRASIL, 2014). Em Arinos, ainda segundo este documento 1.031 é o número de famílias assentadas. A população de Arinos, de acordo com Censo de 2010 (IBGE,, é de 17.674 habitantes. Deste total, 38,5\% reside na zona rural. O município de Arinos ocupa, conforme divulga o Programa das Naçóes Unidas para o Desenvolvimento - PNUD (2013), a 508 a posição em um total de 853 municípios mineiros.

Atualmente, há forte presença da agricultura empresarial, sobretudo na produção de grãos (feijão e milho), com espaço, também, para a pecuária e a agricultura familiar. O rio Urucuia" corta a cidade de Arinos com mais cinco de seus afluentes.

No processo de construção da Escola Chico Mendes, houve um episódio significativo para os assentados e fundamental para entendermos o contexto de criação desses assentamentos. No ano de 2000, os assentados ocuparam a Escola Estadual Major Saint'Clair, no centro da cidade de Arinos por,

II O rio Urucuia é internacionalmente conhecido pela obra de Guimarães Rosa, autor que construiu metáforas existenciais ligando os conflitos do homem aos aspectos da natureza do sertão. 
aproximadamente, uma semana. Nesse ínterim, várias negociaçóes envolvendo lideranças e políticos locais aconteceram até que o governador Itamar Franco autorizasse o funcionamento da escola no assentamento.

A partir daí, a comunidade de assentados, com o apoio do MST, segundo dados das entrevistas realizadas neste artigo, arrecadou doaçóes de colaboradores e da prefeitura. Com esse recurso, adaptaram parte da antiga sede da fazenda desapropriada para que a escola começasse a funcionar. Dentre as instalaçóes reaproveitadas para a escola, estava um curral de bezerros, também chamado pelos alunos de "o barracáo". Foi nesse espaço que aconteceu boa parte das histórias que pais, alunos, professores e lideranças do MST nos contaram. Somente em 2010, um prédio próprio para o funcionamento da escola foi entregue à comunidade.

Atualmente, nos assentamentos pesquisados, algumas famílias optam pelo Ensino Médio na cidade de Arinos, sobretudo o IFNMG. Uma das autoras deste artigo, pedagoga do IFNMG/Arinos, testemunhou as dificuldades de adaptação materializadas no alto índice de reprovação e trancamento de matrículas dos alunos provenientes de assentamentos. Cabe ressaltarmos que o problema da evasáo já era uma realidade do IFNMG. O Tribunal de Contas da Uniáo publicou o acórdão no 506/2013 recomendando à Secretaria de Educação Profissional e Tecnológica em conjunto com os Institutos Federais a realização de planos para aprimorar a atuação relacionada aos problemas de evasão e retenção.

\section{Assentamentos e educação}

Os quatro assentamentos que fazem parte desta pesquisa são acessados pela rodovia MG 202, sentido Arinos/Buritis. A produção de leite é a principal atividade econômica dessas comunidades. Dados divulgados pela Cooperativa Agropecuária Unaí Ltda. (CAPUL) em 2010 revelam que aproximadamente $40 \%$ da captaçáo de leite da cooperativa tem origem nas unidades familiares de produção dos assentamentos rurais (SOUZA, 2010, p. 13). Os quatro assentamentos possuem tanques de resfriamento que foram obtidos pelo Programa Minas Sem Fome, do Instituto Nacional de Colonização e da Reforma Agrária (INCRA), pela própria associação do assentamento, como é o caso do Chico Mendes ou, ainda, de assentados que possuem tanques individuais. A CAPUL é hoje uma das maiores acionistas da Itambé (Cooperativa 
Central dos Produtores Rurais de Minas Gerais) e capta mais de 290 mil litros de leite diariamente.

A maioria das famílias que conhecemos produz algum tipo de alimento, por exemplo: milho, mandioca, abóbora, feijão catador ou melancia. Das dez famílias entrevistadas, apenas duas vendem o que produzem e as demais cultivam apenas para o consumo próprio. Em alguns casos, um dos membros da família cuida da produção para consumo (hortas, pequenas roças, criação de galinhas etc.) enquanto o outro busca trabalho em fazendas próximas ou em empresas que oferecem salário mínimo e carteira assinada. De todas as pessoas que fizeram parte desta pesquisa, apenas duas declararam ter quitado a dívida do primeiro PRONAF. Segundo informaçóes do Sindicato dos Trabalhadores Rurais de Arinos, a inadimplência desses assentamentos gira em torno de 70\%.

Cabe aqui um esclarecimento sobre a atuação do MST nesses assentamentos. Esse Movimento atuou diretamente apenas na formaçáo dos assentamentos Chico Mendes e Carlos Lamarca. Nos assentamentos Roça e Carro Quebrado, a atuação no sentido de reunir os trabalhadores, organizar as ocupaçôes e as negociaçóes com o INCRA foram feitas pelo Sindicato dos Trabalhadores Rurais de Arinos.

\section{I Assentamentos, famílias e educação}

Por falta de espaço neste artigo, os dados sobre as datas de constituição e demais informações sobre os assentamentos estão disponíveis no Anexo 1. O assentamento Chico Mendes vive o início de sua organizaçáo da cidade de Buritis em dezembro de 1999 conforme relato da professora Vilma. A professora Tonica, que trabalhou no acampamento, em entrevista, declarou as condiçóes de ensino da época e ressaltou a falta de higiene como um problema que interferia na aprendizagem (por exemplo: piolhos, bichos-de-pé). As aulas aconteciam sempre à tarde para que os filhos pudessem ajudar no trabalho com a lavoura ou com o leite pela manhá, período de sol mais ameno. Ainda assim, ela entende que a prioridade dos pais sempre foi a escola.

\section{I.2 Quando os assentados se mobilizam...}

Ainda em 2000, os pais passaram a reivindicar uma escola no próprio assentamento. $\mathrm{O}$ insucesso nas tentativas junto à prefeitura municipal levou os assentados, sob a orientação do MST, a realizarem uma mobilização na cidade 
de Arinos. Um assentado ligado ao MST conta que houve uma assembleia para definir os termos da ação de reivindicação:

[...] resolvemos... Foi decidido, em assembleia, que iríamos ocupar a maior escola, na época tida como a escola das elites no centro da cidade, escola Major Saint'Clair. Na época [...] É... Houve grande conflito, grande pressão por parte da administração da época, por parte das lideranças retrógradas do municipio. Então, eles pagaram, incentivaram pra apedrejar o pessoal dentro da escola. (Moisés, assentado do PA Mimoso).

A Senhora Tonica - assentada do PA Chico Mendes, professora do acampamento e do assentamento - associa a reaçáo da populaçáo ao estigma relacionado aos assentados na época junto à população de Arinos:

Na verdade, foi de muito pouco tempo pra cá que a gente conseguiu um certo respeito... Mas, a gente não era bem-visto aqui [...]. E lá dentro dessa escola Major Saint'Clair, teve até uma mãe [grávida] que perdeu o filho dela. Jogaram bomba, como se fosse uma guerra mesmo $[\ldots]$.

O episódio em que a acampada grávida perdeu o seu filho é mencionado por muitos dos assentados. O saldo dessa ação foi a autorização do funcionamento de uma extensão da Escola Estadual Major Saint'Clair no assentamento Chico Mendes com as séries finais do Ensino Fundamental, já que as séries iniciais estavam sob a responsabilidade do município. Para viabilizar o funcionamento das turmas, os assentados adaptaram parte das instalaçóes da antiga sede da fazenda como salas de aula. Dentre essas instalaçóes, estava um curral que foi dividido com placas de Madeirit. Desse momento em diante, os assentados envolveram-se em outra luta, objetivando a construção do prédio da escola. Somente em 2010, o Decreto no 45.519 autorizaria o funcionamento da Escola Estadual Chico Mendes nas novas instalaçóes. Em 2012, o Decreto-Lei no 20.534/2012 criou oficialmente a escola. A escola passou a funcionar em 2011, oferecendo: o Ensino Fundamental do $6^{\circ}$ ao $9^{\circ}$ ano, o programa Reinventando o Ensino Médio (REM), o Projeto de Tempo Integral (PROETI) e a Educação de Jovens e Adultos (EJA) ${ }^{12}$. Além disso, o governo municipal continuou oferecendo, nesse espaço, as séries iniciais do Ensino Fundamental.

12 Os decretos citados são da Secretaria de Estado da Educação de MG. Não estão disponiveis na internet, porém, são mencionados no Regimento Interno e no Projeto Politico Pedagogico da Escola Chico Mendes. Essas fontes não estão disponiveis. 
Ao nos apresentar a escola, a diretora refere-se à quadra de esportes como o "shopping" da comunidade, no sentido de um ponto de encontro de jovens. De acordo com várias pessoas entrevistadas, essa quadra é utilizada livremente pela comunidade, inclusive nos finais de semana, mas apenas para atividades esportivas, sobretudo o futebol, esporte que aparece na fala dos assentados como a única forma de lazer dos jovens.

Quanto ao Projeto Político-Pedagógico da Escola Estadual Chico Mendes no que se relaciona aos princípios, à missão, à visão, aos objetivos e às metas, não há nenhuma referência específica à condição de assentados de seu públicoalvo ou sequer ao fato de ser uma escola de zona rural. Quando perguntamos à supervisora se a escola não desenvolvia nenhum tipo de projeto ligado ao campo, ela mencionou o desejo de que a escola tenha uma horta e um pomar, mas que eles nunca conseguiram levar esse projeto adiante.

\section{Jovens assentados: do curral ao campi do IFNMG}

Algumas famílias assentadas optam pelo Ensino Médio para os filhos no IFNMG. Esta é a realidade de 11 dos 13 alunos cujas trajetórias foram analisadas nesta pesquisa. O IFNMG foi inaugurado na cidade de Arinos no ano de 2009. Uma das justificativas utilizadas para a criação de um campi no Noroeste de Minas foi a alta concentração de propriedades rurais e de assentamentos da reforma agrária. Os baixos níveis de produtividade, renda, e a falta de conexão com os mercados consumidores surgem como preocupaçóes do Plano de Desenvolvimento Institucional (BRASIL, 2009). A consequência seria a migração precoce para os grandes centros como Brasília, São Paulo e Belo Horizonte. E o IFNMG, conforme constatamos, compromete-se a agir na mudança dessa realidade.

Atualmente, o acesso aos cursos superiores do IFNMG acontece por meio do vestibular tradicional e pelo SISU. As vagas são divididas segundo o sistema de cotas: $50 \%$ para ampla concorrência e $50 \%$ para o sistema de reserva de vagas. Os cursos técnicos de nível médio são acessados, com o mesmo sistema de reserva de vagas, por meio de processo seletivo com provas objetivas de Língua Portuguesa e Matemática. Dos alunos que fizeram parte desta pesquisa, apenas dois acessaram o IFNMG por meio do sistema de cotas. Os alunos 
dispóem de bolsas de iniciação científica e de assistência estudantil ${ }^{13}$. A partir de outubro de 2014, o campi passou a ofertar o sistema residencial e o semirresidencial nos quais três dos estudantes entrevistados foram contemplados.

\section{I Trajetórias dos jovens assentados}

Os dados da pesquisa de Carneiro (1998) confirmam que a população jovem e seus pais entendem ser a educaçáo a melhor forma de alcançar uma ocupaçáo mais bem remunerada e menos penosa que a agricultura. Isso aparece igualmente nesta pesquisa, pois 100\% dos jovens entrevistados fizeram referência à escola (ou ao diploma) como imprescindível para alcançar o futuro que almejam. Nesta seção, apresentamos os elementos fundamentais que surgiram nas entrevistas e que mostram as trajetórias escolares dos e das assentadas.

A estudante Joana, 18 anos, vive no assentamento Chico Mendes desde a época do acampamento. Ela e a família vieram do município de Buritis, onde ela estudou até a terceira série. Joana conta que seu pai, o senhor Joaquim chegou ao acampamento já com o primeiro grupo: "[...] ele foi o primeiro acampado, veio no primeiro ônibus". Até então, o Sr. Joaquim era empregado em fazendas na região e a mãe de Joana lavava roupas "para fora”.

$\mathrm{Da} 4^{\mathrm{a}}$ a $8^{\mathrm{a}}$ série, Joana estudou no barracáo (local que alguns também chamam de curral) do Chico Mendes. Ela declara ter sofrido discriminação por parte de suas colegas da cidade que ironizavam suas vestimentas. Joana não nos contou essa história com lamentos ou pessimismo:

[...] quando eu tava dentro do Instituto, ali que eu olhava pra trás. Imaginava, gente... Olha a facilidade que eu tenho pra estudar hoje! [...] acho que se eu não fizer alguma coisa do futuro, aquela luta que eu tive não vai valer a pena, sabe? E eu sou muito orgulhosa de ter, pelo menos, o técnico em agropecuária.

João tem 17 anos, cursa o segundo ano do curso técnico em agropecuária integrado ao Ensino Médio no IFNMG, e vive com a máe (35 anos), o pai (42 anos) e dois irmãos. Seu pai é produtor de leite e secretário da associaçáo

13 O Programa de assistência estudantil é composto pelas modalidades de auxilio-alimentação ( 120 reais durante nove meses), auxílio-transporte (70 reais durante nove meses), auxílio-moradia (140 reais durante 12 meses), auxilio-permanência (300 reais durante 12 meses), auxilio para compra de itens escolares, uniforme, cópia e impressão (20 reais mensais durante um ano letivo). 
dos produtores no assentamento. A renda da família vem do leite (entre 1.100 e 1.200 reais) e do Programa Bolsa Família. Além da bolsa de iniciação científica no valor de 100 reais que recebeu durante todo o ano de 2014, Joáo recebe o auxílio- transporte. Seus pais frequentaram a escola até a $5^{\mathrm{a}}$ série. Eles vieram de Unaí, onde viviam nas terras do avô de João e também produziam leite. Quando souberam do acampamento do MST por meio de conhecidos, decidiram tentar a conquista da própria terra, entrando para a ocupaçáo.

João ingressou no IFNMG no Ensino Médio (por incentivo de seus professores da escola de Uruana), só que foi reprovado no $1^{\circ}$ ano. Para ele, essa reprovação foi fruto de sua dificuldade em entender as matérias e por não conhecer como as coisas funcionavam no Instituto. A compreensão desse aluno evidencia, mais uma vez, a internalizaçáo do fracasso mencionada por Bourdieu $\left(2013^{a}\right)$. No entendimento de sua mãe, Dona Josefa, a reprovação de Joáo aconteceu porque o IFNMG é uma escola muito diferente da escola municipal que ele estudava: "Que lá, o Instituto é um serviço melhor... É um estudo melhor, né? Que o aluno tem que se esforçar mais”. Ela vê maiores expectativas para o filho agora, mesmo depois da reprovação. Para João, a maior prova da participação do pai em sua vida escolar foi o incentivo, por influenciar a escolha do curso e consultar o filho sobre questóes técnicas: "[...] ele fica perguntando e tenta aprender comigo". Dona Josefa revela que vai à escola quando tem reunióes, mas que se encontra muito pouco com Joáo para acompanhar seus estudos.

A rotina de João e de todos os demais entrevistados é acordar muito cedo, voltar para casa tarde e já tomado pelo cansaço, o que dificulta os estudos. Após sua entrada no IFNMG, os pais adquiriram um computador e instalaram internet. Ele tem uma mesa em seu quarto para estudar. $\mathrm{O}$ jovem diz que utiliza a internet para estudar, mas que também gosta muito de acessar o Facebook e jogos. Sua principal forma de lazer é o futebol com os amigos. João pretende continuar estudando, deseja cursar Agronomia no IFNMG. Joáo declara que nunca se sentiu discriminado, que achou estranho os apelidos (os quais, não menciona por constrangimento) que ganhou no primeiro ano; mas, entende que isso era feito com todos os calouros. Declara estar feliz porque, na escola, o internato e o refeitório vão começar a funcionar ainda em 2014. Apesar das dificuldades, ele diz que não vai desistir: "[...] eu acho que tudo o que é difícil, no final é bom. Por isso, que eu tô lutando. Tanto é que eu 
quero dar um orgulho a meu pai, tirar ele dessa vida aqui na roça”. Em outubro de 2014, três meses depois desta entrevista, João foi contemplado no sistema semirresidencial e hoje almoça no refeitório do IFNMG.

Júlio tem 17 anos e mora com dois irmáos, o pai (40 anos) e a mãe (36 anos) que está grávida. Ele cursa o $2^{\circ}$ ano do curso técnico em agropecuária integrado ao Ensino Médio. A mãe, dona Aparecida, conta-nos que seu marido trabalhava com o lote, mas que optou por buscar serviço fora desde que Júlio entrou no IFNMG. Segundo ela, a mudança no trabalho objetiva oferecer melhores condiçóes financeiras para apoiar o filho nos estudos. Seu marido hoje possui "registro na carteira" como auxiliar de serviços gerais na empresa Panambi, e recebe um salário mínimo. Dona Aparecida é beneficiária do Programa Bolsa Família. Ela declara que seu filho, sempre que pode, aos sábados, ajuda o vizinho a vender hortaliças na cidade, de "porta em porta". Júlio declara que quando as vendas são ruins, ele recebe entre 15 e 20 reais, mas que já alcançou 50 reais. O dinheiro é utilizado na escola, para lanchar. Das famílias entrevistadas nesta pesquisa, dona Aparecida é a única mãe que cursa o Ensino Médio e o está concluindo na cidade de Arinos. Do início da trajetória escolar dos filhos, ela recorda as dificuldades quando ainda moravam no acampamento: "Às vezes, tinha que sair quatro horas da manhä, vestir sacolinha nas pernas deles pra não sujar os pés, debaixo de chuva".

Júlio cursou todo o Ensino Fundamental em Uruana de Minas e, no Ensino Médio, foi estudar no IFNMG. No primeiro ano, seus pais pagavam aluguel para que ele morasse na cidade de Arinos com outros colegas. Nesta série, ele foi reprovado e atribui o acontecimento a má adaptação, falta de interesse dele e falta de acompanhamento dos pais. Sua mãe também entende que ter morado sozinho favoreceu a reprovação de Júlio: "[...] eu acho assim que se eu tivesse perto dele igual hoje, eu acho que tinha sido melhor. Eu acho que os pais ajuda muito também na vida escolar dos filho, náo só os professor". Dona Aparecida acredita também que a falta de um computador e de internet para estudar pesou muito na reprovação do filho. Por isso, ela comprou um notebook em nove prestaçóes (custou quase 3 mil reais) no intuito de evitar que o filho seja reprovado novamente.

Hoje é o próprio Júlio quem paga a internet com o dinheiro da bolsa de iniciação científica que recebe. Ele trabalha em um projeto sobre qualidade e sanidade de sementes. Júlio declara utilizar a internet para filmes e acessar o 
Facebook ou, com menor frequência, ler algum artigo científico. $\mathrm{O}$ aluno nos conta que não tem um espaço específico (como uma mesa) para estudar em casa e que tem o hábito de procurar um lugar tranquilo na roça mesmo para sentar no chão e estudar. Dona Aparecida espera que o filho faça um curso superior. $\mathrm{O}$ entusiasmo de Júlio com os estudos é marcante:

Olha só... Eu não vou descansar enquanto eu não tiver um mestrado, um doutorado na mão. Eu quero continuar estudando, e, pra mim, não importa se for Agronomia, Engenharia Civil... É o que Deus me der. E o que eu der conta, tiver mais perto do meu alcance, eu vou fazer. [...] Eu espero um futuro brilhante.

Para Júlio, ser assentado é difícil. Declara que os assentados são uma sociedade à parte, excluída da "outra sociedade" porque "alguns benefícios não chegam". Ele entende que uma escola como o IFNMG parece não ter sido feita para os assentados: "É como se um assentado não pudesse estudar numa escola tão... Assim... Bem construida, né? Uma instituição bem feita, bem materializada". Segundo Júlio, poucos conseguem acessá-la em virtude da "boa educaçáo" que não tiveram no Ensino Fundamental. Ele conta que sua mãe dá atenção ao que ele faz, verifica se ele está estudando em casa e cobra um bom desempenho, ao mesmo tempo em que confia nele. Ele declara ter uma boa relação com todos os seus colegas do IFNMG inclusive os que moram na cidade. Porém, deixa implícito, em sua fala, que alguns comentários preconceituosos o deixam ofendido:

[...] eu não culpo as pessoas por ter... Não culpo aonde eu moro. Se eu sou negro... Mas eu culpo as pessoas, porque não tem ainda maturidade. Os meus colegas ainda são adolescentes; então, não têm maturidade. Leva tudo na brincadeira... Mas que... Machucam aquela pessoa que tá ouvindo ou que tá recebendo aquelas críticas.

Conforme Theodoro $(2008$, p. 134) a discriminação racial direta através de "injúrias" é classificada no Brasil como crime desde o final da década de 1980; porém, o recurso jurídico é pouco mobilizado. No relato de Júlio, ele relativiza a injúria por parte dos colegas de sala e ainda a justifica como imaturidade.

Alice, do assentamento Carro Quebrado, tem 18 anos, é aluna do $3^{\circ}$ ano do Curso Técnico em Agropecuária Integrado ao Ensino Médio. Em 2014, ela morava em Arinos com os irmãos, para estudar. Seu pai é separado da mãe e trabalha como tratorista. Sua mãe, dona Dorinha, ficou 
com o lote e, com a ajuda de um vizinho, entrega leite para a cooperativa. Ela tem 38 anos e vive há 13 anos no assentamento. É uma pessoa ativa na comunidade em virtude dos seus trabalhos na Pastoral da Criança e de ser presidente da associação do assentamento. Ela tem várias ocupaçóes e trabalha sozinha no lote (seus filhos já não moram mais no assentamento). Dona Dorinha recebe em média 400 reais mensais pelo leite que consegue entregar. Dois dos seus quatro filhos trabalham, e Alice recebe assistência estudantil.

Antes do assentamento, dona Dorinha trabalhava como empregada doméstica em Arinos enquanto seu ex-marido trabalhava em fazendas na região. Ambos estudaram até a $4^{\mathrm{a}}$ série. Dona Dorinha e seus filhos não ficaram acampados, apenas seu ex-marido. Ela veio apenas depois que o assentamento se organizou. Alice começou a estudar na cidade de Arinos e somente na $8^{\mathrm{a}}$ série e no $1^{\circ}$ ano do Ensino Médio estudou na escola Chico Mendes. Sobre a vida no assentamento, ela enfatiza a dificuldade para estudar: "Porque lá [assentamento] não era tão bom assim. A gente foi um dia e a gente já não gostou [...]. Aí minha máe ficou meio com medo e a gente vinha pra Arinos”. Dessa forma, Alice acordava às $4 \mathrm{~h}$ da manhá porque a mãe andava em torno de oito quilômetros de charrete para levá-la ao ponto de ônibus. Ela diz que viver no assentamento é tranquilo, mas que não gostaria de voltar para lá porque quer buscar coisas novas: “...] eu não voltaria não, porque lá... Tipo assim, não oferece emprego pra mim, nenhuma renda pra mim viver. Basicamente, ia viver às custas dos meus pais". Alice optou por repetir o primeiro ano do Ensino Médio para estudar no IFNMG, onde, em virtude da modalidade de ensino técnico integrado ao médio, náo poderia ingressar já no segundo ano. Ela declara que nunca havia sido reprovada e que repetiu essa série consciente de que valeria a pena.

Quando entrou no IFNMG, Alice teve dificuldades com as disciplinas da área de exatas. Apesar de náo morar com os pais, ela mantém a mesma rotina de estudos e declara que a máe sempre perguntou sobre a escola, sempre compareceu às reunióes; porém, o pai é mais "desligado". Sua mãe comprou um computador quando seu irmáo mais velho (que concluiu o curso e vive em Goiás) entrou no IFNMG. Sendo assim, Alice teve computador e internet em casa durante os três anos do curso. A casa em que Alice, seu irmáo mais velho e sua irmã mais nova vivem em Arinos é própria. É uma pequena casa que parece ter sido reformada, é organizada e aconchegante. $\mathrm{O}$ computador 
da família fica na sala e em um móvel apropriado com uma cadeira. Esta aluna estuda nos períodos da manhã e da tarde. No horário de almoço, era ela mesma quem cozinhava até o mês de outubro de 2014, quando o refeitório da escola passou a funcionar. A hierarquia entre seus afazeres e as atividades escolares fica evidente quando perguntamos sobre sua rotina semanal: "Eu chego às 16h20min. Quando eu chego, eu vou lavar roupa, vou arrumar casa, varrer terreiro. Ai, quando sobra um 'tempim' à noite, eu faço as atividades da escola".

No final de 2014, depois da formatura, Alice revela que iria embora para outro estado, no norte do país. Ela iria se casar e, por isso, não tentaria vestibular por enquanto. Diz que ainda não sabe o que vai fazer, o sonho é passar em um concurso público, preferencialmente na área agrária.

Na família de Alice, chamou-nos a atenção o empenho de sua mãe para que ela e seus irmãos estudassem. O filho mais velho está cursando o último ano do Bacharelado em Administração em uma faculdade particular na cidade de Unaí e foi ela quem pagou suas mensalidades por um ano e meio (vendendo roupas como sacoleira) até que ele conseguisse um emprego em um banco de Arinos. E esse emprego hoje garante o pagamento da faculdade e das despesas com a casa em Arinos, onde mora com duas irmás. O outro filho de dona Dorinha é egresso do IFNMG onde fez o Curso Técnico em Agropecuária. Ele mora na cidade de Formosa, em Goiás, onde trabalha em um laboratório de análise de solos (e assim paga suas despesas) e faz um curso superior de Química, em que foi aprovado no final de 2014. A filha mais nova cursa o Ensino Fundamental no Colégio Objetivo, instituição particular em Arinos como bolsista. Dona Dorinha fala com orgulho da trajetória escolar de seus filhos: "O meu sonho é de todos ter o superior [...]. E quero assim que Deus abençoe que eu vou realizar o meu sonho".

O aluno Felipe tem 17 anos, estuda no segundo ano do curso técnico em agropecuária integrado ao Ensino Médio e mora no Assentamento Carro Quebrado. Seus pais cursaram apenas o Ensino Fundamental. A mãe (40 anos) é dona de casa e o padrasto (60 anos) é catireiro: "compra e vende gado, semente, tudo, essas coisa assim. Tira um leite, essas coisas assim". A renda líquida da família é de 1.200 reais. Felipe veio de Goiás aos seis anos de idade e morou na cidade de Arinos até os 11 anos, quando foi para o assentamento. Em Arinos, estudou em três escolas públicas, e no Chico Mendes estudou da $5^{\mathrm{a}}$ a $8^{\mathrm{a}}$ série. No primeiro ano do Ensino Médio, Felipe passou a estudar no IFNMG 
e foi reprovado nesta série. Quando repetiu a série, Felipe diz que foi mais fácil e que, de lá pra cá, estuda pouco, meia hora por dia, ou uma semana antes das provas. $\mathrm{O}$ aluno diz que sua mãe confia nele e em seu método de estudo, mas que náo deixa de reclamar porque ele pega no livro poucas vezes ou porque vive jogando no computador.

Para Lahire (2008), as famílias das classes populares tentam compensar o auxílio escolar que não conseguem oferecer, através de práticas de controle como esta, monitorando o tempo dedicado às tarefas ou controlando o tempo dedicado a outras atividades como televisão ou saídas com os amigos. Segundo o autor, embora a intervenção dessas famílias se limite aos domínios periféricos das práticas escolares, ainda assim, são de relevância.

A internet de Felipe é paga por ele próprio. Ele declara que acessa o Facebook, ouve música, joga e faz pesquisas escolares. Felipe é bolsista do Programa de Iniciação Científica Júnior em um projeto de caracterização de sementes de feijão. Nos finais de semana, ajuda o padrasto e, às vezes, sai para jogar bola. Ele gosta de morar no assentamento pela tranquilidade, mas pretende sair assim que terminar o Ensino Médio. Entre seus planos, estão cursar a Faculdade de Agronomia ou conseguir um emprego de técnico em agropecuária em uma fazenda em Goiás, onde seu pai mora. Em sua opiniáo, a vida de estudante não é diferente para um assentado. Declara que nunca se sentiu discriminado no IFNMG, apenas se incomodou com os apelidos, mas que fez amigos da cidade. Desde outubro de 2014, Felipe mora no campi, pois foi contemplado no sistema residencial. Ele declara que os trabalhos em grupo agora são feitos com os colegas residentes; porém, antes, seu grupo de estudos sempre havia sido os colegas assentados. Declara que seu futuro será bom e que a escola o está preparando: "Tudo que vim lá na frente, acho que eu já tô pronto pra mim resolver sozinho".

Cláudia tem 25 anos e mora com o marido em uma casa alugada em Arinos há poucos meses. Ela faz faculdade pela manhã e trabalha em uma padaria (onde tem carteira assinada e recebe um salário mínimo) nos períodos da tarde e noite. Seu marido trabalha como pedreiro e não tem renda fixa. Cláudia veio do assentamento Carro Quebrado e mora em Arinos desde 2010, quando passou a estudar no IFNMG. Seu pai (55 anos) e sua mãe (47 anos) continuam no assentamento e a renda da casa vem do Benefício de Prestação Continuada (BPC) que seu pai recebe por um problema na coluna e do Programa Bolsa Família. 
Os pais de Cláudia deixaram a casa do avô onde viviam, em Morrinhos (Distrito de Arinos). A família mudou-se para o acampamento Regalito, no mesmo distrito. Como o INCRA náo efetivou a desapropriaçáo daquela fazenda, a alternativa foi a mudança para o acampamento Carro Quebrado. Ela nos conta que ficou até os oito anos de idade sem estudar, até que uma sala de aula cercada com tela foi improvisada no acampamento. Sua turma era multisseriada ( $1^{\mathrm{a}}$ a $4^{\mathrm{a}}$ séries) e com uma professora que havia cursado apenas até a $8^{\text {a }}$ série.

O Ensino Médio foi cursado em uma escola estadual na cidade de Arinos, no período noturno. Cláudia declara nunca ter sido reprovada; no entanto, não se sentia preparada para o ensino superior por considerar que o Ensino Médio foi "fraco". Foi assim que ela decidiu cursar o Ensino Médio pela segunda vez, agora no IFNMG de forma integrada ao curso técnico em informática. Ela declara dificuldades especialmente pela falta de um computador. Cláudia fazia seus trabalhos práticos em Lan Houses (quando havia dinheiro) ou na casa de colegas. Da época do curso técnico, ela tem na memória o sentimento de rejeição pelos colegas: "Eles não diziam nada; mas, eu ficava lá excluida num canto". A jovem diz que seus colegas assentados na época náo diziam de onde vinham e se relacionavam melhor por isso. Ela relata que a ajuda dos pais consistia apenas na compra de materiais, quando possível. Durante os três anos do Curso Técnico em Informática, Cláudia morou na casa de uma tia em Arinos. Nessa época, a aluna foi contemplada com o auxílio-permanência, o que, segundo ela, possibilitou que ajudasse os pais que passavam por muitas dificuldades econômicas no assentamento.

Em 2014, Cláudia cursava o $2^{\circ}$ ano do curso superior de Tecnologia em Produçáo de Grãos no IFNMG, casou-se e foi morar com o companheiro. Como egressa de um curso técnico do IFNMG, optou por fazer o vestibular na mesma Instituição e foi classificada em primeiro lugar, utilizando o sistema de cotas. Cláudia pretende ajudar os pais com o conhecimento técnico e, no futuro, prestar assistência técnica aos assentados. Ela compreende sua mudança para a cidade como um passo positivo: "daqui, eu só quero subir mais". Da experiência de ser assentada, ela fala com tristeza das dificuldades relacionadas a morar na roça, da falta de chuvas, da degradaçáo do solo: "Era muito difícil, porque aquele tempo minha mãe e meu pai não tinha auxilio nenhum, sabe? Então, a gente vivia do trabalho braçal mesmo do meu pai, que trabalhava pros outros. Passamos muita precisão [...]". 
Voltei a conversar com Cláudia quatro meses depois da primeira entrevista, ela contou que precisaria deixar o emprego para fazer o estágio e o TCC do seu curso porque náo poderia mais adiar (já é o último ano). Cláudia, por fim, comentou que ainda não sabia como iria manter-se financeiramente em 2015.

Francisco tem 21 anos e cursava, em 2014, o $3^{\circ}$ ano do curso técnico em agropecuária integrado ao Ensino Médio. Ele veio do assentamento Roça em 2011 para estudar no IFNMG e mora sozinho em um barracão (construído nos fundos de um terreno de sua irmã). Na casa principal, moram suas sobrinhas que também estudam em Arinos. Francisco nos conta que o barracão foi construído com a ajuda financeira do seu pai, mas que o dinheiro que recebe da assistência estudantil (300 reais mensais) foi essencial para que a obra fosse feita. Ele conta que suas condiçóes de vida e estudo melhoraram bastante desde que passou a morar "em seu próprio lar". Foi lá que ele nos recebeu para a entrevista.

Francisco vivia com o pai ( 49 anos) e a mãe ( 55 anos) no assentamento, ambos possuem o Ensino Fundamental incompleto ( $3^{\mathrm{a}}$ e $5^{\mathrm{a}}$ série, respectivamente) e trabalham com a produção de leite. Eles são cooperados e utilizam o tanque comunitário. A renda mensal da família é em média de 1.200 reais, um valor que varia muito em virtude da oscilação do preço do leite. Além do auxílio- permanência, Francisco conta que em 2013 foi bolsista do Programa de Iniciaçáo Científica Júnior em um projeto com sementes de Baru.

Francisco declara que morou na cidade de Arinos quando criança. Os primeiros anos na escola foram difíceis, porque ele não conseguiu se adaptar e ficou estudando em casa com uma professora particular. Quando seu pai conseguiu o lote no assentamento, a mãe providenciou a mudança dos dois e sua matrícula na Escola Chico Mendes. Já em seu primeiro ano na nova escola, Francisco foi reprovado (ele cursava a segunda série). Desta experiência no Chico Mendes, ele se recorda antes da dificuldade que enfrentava para chegar à escola do que das condiçóes de aprendizagem:

Naquela época o transporte era muito difícil. E, como a fazenda (termo que ele e outras pessoas usam para se referir aos assentamentos) do meu pai lá é longe da escola, do colégio [...] e naquela época chovia muito [...], tinha vez que os professor não queria deixar a gente entrar porque tava sujo, entendeu?

No ano seguinte, Francisco passou a estudar em uma escola na sede do próprio assentamento Roça. Lá estudou por um ano e foi reprovado novamente. 
Concluiu a $4^{a}$ série na escola do assentamento Roça e retornou ao Chico Mendes para cursar da $5^{\mathrm{a}}$ até a $8^{\mathrm{a}}$ oitava série. Nos anos finais do Ensino Fundamental, não foi reprovado em nenhuma série. No Ensino Médio, passou a cursar o Técnico em Agropecuária integrado ao Ensino Médio no IFNMG. Ele foi reprovado no $1^{\circ}$ ano e acredita que sua timidez (falta de interação com os colegas e professores) aliada à falta de um computador para estudar e fazer pesquisas e ainda o ritmo "mais puxado" da escola contribuíram para isso.

Francisco declara ter sofrido preconceito por parte dos colegas no IFNMG. Ponderou, ainda, que seus pais o ajudaram a superar o preconceito e que hoje tem muitos amigos na sala. Esse jovem declara que "vive para estudar" e que a dificuldade que enfrenta ainda é a falta da internet, pois agora já tem um notebook usado (objeto que exibe com um sorriso) que ganhou de sua prima. Ele contorna a falta da internet salvando o material que consegue enquanto está no Instituto. Ele declara que usa o Facebook; entretanto, dá preferência aos assuntos da escola quando acessa a internet. Francisco afirma que visita raramente os pais. Seus pais também náo vão à escola, segundo ele, em razão da atividade leiteira e das criaçóes. Ele nos conta que os pais sempre o incentivaram a continuar, mesmo depois da reprovação. Apesar de morar na cidade, o dia de Francisco começa táo cedo quanto o dos seus colegas que moram nos assentamentos, já que ele é o responsável pelas próprias refeiçóes.

Francisco costuma ficar na escola depois do horário para participar de plantôes, monitorias e grupos de estudos. Ele aponta sua estratégia de solicitar os slides de aula com os professores como apoio para o estudo em casa, bem como listas de exercícios - inclusive em períodos de férias. Ele declara que estuda igualmente nos finais de semana já que não tem interesse em sair para se divertir. O desejo de Francisco era o de fazer vestibular para Agronomia no próprio IFNMG quando terminasse o Ensino Médio. Aqui, igualmente, vislumbra-se a proposta de Lahire (2001) do distanciamento do caráter homogeneizador das disposiçóes: há um tempo investido no domínio escolar em sacrifício do tempo doméstico, de lazer.

Francisco formou-se técnico em Agropecuária e não foi aprovado na primeira lista no vestibular para Agronomia no IFNMG. Encontramos o jovem nos corredores da Instituição em fevereiro deste ano e ele declarava, entusiasmado, que tinha conseguido uma proposta de emprego com carteira assinada. O jovem vai atuar e morar em uma fazenda como técnico em sua área de 
formação. Perguntamos a ele sobre o sonho de fazer Agronomia, ao que ele respondeu que ainda tinha esperanças de entrar no curso, pela lista de espera do SISU. Duas semanas depois do nosso encontro, Francisco foi chamado pela referida lista; porém, não compareceu.

As trajetórias apresentadas mostram situaçôes heterogêneas. A mobilização familiar em torno da vida escolar dos filhos e filhas, as práticas de socialização e transmissáo de valores, o contorno da trajetória social e escolar podem tornar-se fatores escolarmente rentáveis (ZAGO, 2011, p. 35). O conceito de configuração social de fatores (não como somatória de elementos antes nas relaçôes de interdependência) é pertinente para a análise proposta. As trajetórias são singulares, não como casos excepcionais, antes, como combinaçóes específicas de traços pertinentes (LAHIRE, 2008). É flagrante, na rotina destes estudantes, a experiência de segregação no IFNMG. Como aponta Van Zanten (2010), famílias de classe média com peso maior do capital econômico em relação ao capital cultural tendem a enxergar desfavorecidos e imigrantes como "diferentes de si"; nesse sentido, evitam escolas com esses públicos. No caso dos estudantes assentados, eles é que vão frequentar escolas onde um público de classe média e que mora na cidade de Arinos já ocupa os espaços do IFNMG e s segrega.

\section{Considerações finais}

A vida cotidiana e estudantil de crianças e adolescentes em idade escolar nos espaços de reforma agrária pode ser bastante "dura". A dificuldade em manter um padrão de vida minimamente digno em locais onde a alimentação e a higiene são precárias aliadas ao constrangimento de ser mal recebido na escola, tornam ainda mais penosas as experiências escolares. Rotinas que começam às 5 h da manhá, pés cheios de lama na estrada até a escola e comida requentada são parte de um percurso difícil. $O$ "futuro brilhante" aparece (fora raras exceções) longe da roça, longe do assentamento, visto que há a expectativa de assegurar, além do próprio futuro, uma "boa" velhice aos pais.

Predominam, nos projetos de futuro tanto dos pais quanto dos estudantes, a ideia de sair do campo e de que a educação formal é uma estratégia nesse sentido. Entáo, questionamos: é possível afirmar que os assentamentos produzirão o abandono da vida no campo para as gerações futuras? Os dados desta pesquisa apontam nesta direção; porém, mais pesquisas nesta área seriam bem-vindas. 
Há um processo de segregação vivido pelos estudantes no IFNMG. Nas falas dos alunos, pouco aparece a socialização com colegas da cidade. O constrangimento e o preconceito sofridos sáo tais que, no IFNMG, os estudantes oriundos dos assentamentos tentam se separar desta identidade considerada pejorativa. Além disso, vivenciam a desvalorizaçáo do mundo rural no espaço urbano, sendo tachados como atrasados, roceiros. Referindo-se ao IFNMG, um jovem aluno afirma: "É como se uma escola desse porte não fosse feita para a gente". Bourdieu (2013b) menciona a noção do trânsfuga para se referir àqueles com inserção simultânea em dois grupos sociais, explicando os custos emocionais dessa inserção. Lahire (2003) generaliza essa noção de multipertencimento social fenômeno que, sobretudo no mundo contemporâneo, produz o "homem plural". Entre nossos entrevistados, igualmente há um duplo estrangeirismo: nem os estudantes se sentem participantes do meio rural (em alguns casos, desejam uma profissão para sair do campo) nem se sentem integrados no espaço urbano proporcionado pelo IFNMG.

Retomando as reflexóes deste artigo, os dados indicam grande esforço das famílias de baixa renda e assentadas (desprovidas do capital cultural e material) no sentido da escolarização dos filhos. Elas contribuem na construção de uma trajetória escolar com relativo sucesso. Mesmo sem o capital escolar (possuem, geralmente, o Ensino Fundamental incompleto) essas famílias operam uma ordenação racional que prepara os filhos para o disciplinamento dos “jogos escolares". Existe um senso prático por parte dos pais, no sentido de auxiliar os filhos na compra de computadores (mesmo que eles não saibam exatamente para qual finalidade) e de dispensá-los do trabalho para que se dediquem ao estudo. Embora os pais incorporem as "regras do jogo", isto é insuficiente para que os filhos superem as dificuldades escolares. Há um capital cultural objetivado; contudo, com a ausência do capital cultural incorporado, o computador não é suficiente para contornar a reprovaçáo escolar.

De outro lado, longe da tragédia estatística, a ideia da repetência voluntária no IFNMG aparece elaborada nas falas de dois estudantes como uma estratégia pessoal: repetir para conseguir acompanhar o curso nos próximos anos. Uma das alunas optou por refazer todo o Ensino Médio junto ao Técnico de Informática. Ao mesmo tempo em que ocorre uma internalizaçáo do fracasso, os testemunhos dos alunos trazem as dificuldades econômicas, as distâncias a percorrer até a escola. Eles elaboram igualmente a falta de condiçóes objetivas 
para os estudos. Há, portanto, uma ambivalência entre assumir os fracassos e apontar as desigualdades.

Esta pesquisa sugere que as instituiçóes de educação da região, em particular o IFNMG, podem intervir nessa realidade reformulando seus espaços e formas de atuação, bem como seus projetos pedagógicos. Dentro do IFNMG seriam bem-vindas ações de recepção e acolhimento dos assentados, tanto para orientar esses jovens e suas famílias como para orientar o restante dos alunos no sentido de aproximar os dois públicos de estudantes. É importante, ainda, retomarmos a visão de Bourdieu, distante dos apontamentos de Zago (2011), com relação às camadas populares, já que, nesta pesquisa, constatamos que as famílias se mobilizam poupando seus filhos do trabalho durante três anos (ou mais, no caso dos que reprovam) para estudar. Isso, evidentemente, reposiciona a trajetória e a aspiração desses estudantes. Em consonância com as descobertas de Vianna (2011) e seguindo as críticas de Lahire às disposiçóes muito rígidas da proposta de Bourdieu, nesta pesquisa também foi possível constatarmos como a autodeterminação desses estudantes se constrói no processo da escolarização, sem existência a priori.

\section{Referências}

ALVES, M. T. G. et al. Fatores familiares e desempenho escolar: uma abordagem multidimensional. Dados - Revista de Ciências Sociais, Rio de Janeiro, v. 56, n. 3, p. 571- 603, 2013.

BOURDIEU, P. A escola conservadora: as desigualdades frente à escola e à cultura. In: NOGUEIRA, M. A.; CATANI, A. (Org.). Escritos de Educação. Petrópolis: Vozes, 2013a. p. 39-64.

Classificação, desclassificação, reclassificação. In: NOGUEIRA, M. A.; CATANI, A. (Org.). Escritos de Educação. Petrópolis: Vozes, 2013b. p. 145-183

. Os excluídos do interior. In: NOGUEIRA, M. A.; CATANI, A. (Org.). Escritos de Educação. Petrópolis: Vozes, 2013c. p. 217-227

. Os três estados do capital cultural. In: NOGUEIRA, M. A.; CATANI, A. (Org.). Escritos de Educaçáo. Petrópolis: Vozes, 2013d. p.71-79

.; PASSERON, J.-C. Os herdeiros: os estudantes e a cultura. Florianópolis: Editora da UFSC, 2014. Não foi citado RETIRA

BRASIL. Ministério da educação. Pesquisa nacional da Reforma Agrária (PNERA). 2005. Disponível em: <http://www.lepel.ufba.br/PNERA.pdf>. Acesso em: 25 nov. 2014. 
- Secretaria de Desenvolvimento Territorial. Ministério do Desenvolvimento Agrário. Plano de Desenvolvimento Institucional. a (esta referência entra no lugar do INCRA)Instituto Federal de Educação, Ciência e Tecnologia do Norte de Minas Gerais, 2009.

Relatório Analítico do Território Rural Noroeste de Minas.

Uberlândia, 2014a. Não foi citado no texto RETIRA

Ministério do Desenvolvimento Social e Combate à Fome. Bolsa Família. 2014b.

Disponível em: < http://mdspravoce.mds.gov.br/bolsa-familia/>. Acesso em: 11 maio 2014. Não foi citado no texto retira

CARNEIRO, M. J. Juventude rural: projetos e valores. In: ABRAMO, H. W.; BRANCO, P. M. (Org.). Retratos da Juventude Brasileira: análises de uma pesquisa nacional. São Paulo: Fundação Perseu Abramo; Instituto Cidadania, 1998. p. 243- 261.

LAHIRE, B. Le travail sociologique de Pierre Bourdieu. Dettes et critiques. Paris: La Découverte, 2001.

O homem plural. As molas da acção. Editora Instituto Piaget, 2003.

. Sucesso escolar nos meios populares: as razões do improvável. São Paulo: Ática, 2008.

LEITE, S. et al. Impactos dos assentamentos: um estudo sobre o meio rural brasileiro. Brasília; São Paulo: Instituto Interamericano de Cooperação para a Agricultura; Unesp, 2004.

PROGRAMA DAS NAÇÓES UNIDAS PARA O DESENVOLVIMENTO (PNUD). Atlas do Desenvolvimento Humano dos Municípios. 2013. Disponível em: <http://www.pnud.org.br/ IDH/Default.aspx?indiceAccordion=1\&li=li_AtlasMunicipios>. Acesso em: 11 maio 2014.

SOUZA, D. N. A influência dos assentamentos rurais na dinamização do Noroeste Mineiro: o que pensa a população urbana? In: CONGRESSO LATINO-AMERICANO DE SOCIOLOGIA RURAL, 8., 2010, Porto de Galinhas. Anais eletrônicos... Porto de Galinhas, 2010. Disponível em: <www.alasru.org/grupo-de-trabajo-15-brasil>. Acesso em: 21 jan. 2015.

THEODORO, M. (Org.). As políticas públicas e a desigualdade racial no Brasil: 120 anos após a abolição. 1. ed. Brasília: Ipea, 2008. Disponível em: <http://www.mpgo.mp.br/portalweb/hp/41/ docs/desigualdades_raciais.pdf $>$. Acesso em: 21 jan. 2015.

VAN ZANTEN, A. A Escolha dos outros: julgamentos, estratégias e segregaçóes escolares, Educação em Debate, Educação em Revista. Belo Horizonte, v. 26, n. 3, p: 409-434, dez. 2010. Disponível em: <http://www.scielo.br/pdf/edur/v26n3/v26n3a21.pdf>. Acesso em: 21 jan. 2015. 
VIANA, M. J. B. Longevidade escolar em famílias de camadas populares. In: NOGUEIRA, M. A. et al. (Org.). Família e escola: trajetórias de escolarização em camadas médias e populares. Rio de Janeiro: Vozes, 2011. p. 45-60.

ZAGO, N. Processo de escolarizaçáo nos meios populares - As contradiçóes da obrigatoriedade escolar. In: NOGUEIRA, M. A. et al. (Org.). Família e escola: trajetórias de escolarização em camadas médias e populares. Rio de Janeiro: Vozes, 2011. p. 17-43.

Recebido em: 10.07.2015

Aceito em: 20.10.2015

\section{Anexos}

Anexo I - Assentamentos da região de Arinos

\begin{tabular}{|l|l|l|l|l|l|}
\hline Assentamento & $\begin{array}{l}\text { Portaria/ } \\
\text { ano de } \\
\text { criação }\end{array}$ & Origem & $\begin{array}{l}\text { Distância de } \\
\text { Arinos }\end{array}$ & $\begin{array}{l}\text { Origem do nome } \\
\text { do assentamento }\end{array}$ & $\begin{array}{l}\text { Número de } \\
\text { famílias }\end{array}$ \\
\hline Chico Mendes & $21 / 2000$ & $\begin{array}{l}\text { Fazenda } \\
\text { Roça }\end{array}$ & $30 \mathrm{~km}$ & Mística MST & 136 \\
\hline Carlos Lamarca & $44 / 2000$ & $\begin{array}{l}\text { Faz São } \\
\text { Miguel de } \\
\text { Mulungu }\end{array}$ & $27 \mathrm{~km}$ & Mística MST & 84 \\
\hline Carro quebrado & $60 / 1998$ & Faz. Roça & $28 \mathrm{~km}$ & $\begin{array}{l}\text { Escolha dos } \\
\text { assentados (sem } \\
\text { envolvimento com } \\
\text { o MST) }\end{array}$ & 36 \\
\hline Roça & $23 / 2000$ & Faz. Roça & $34 \mathrm{~km}$ & $\begin{array}{l}\text { Escolha dos } \\
\text { assentados (idem) }\end{array}$ & 36 \\
\hline
\end{tabular}

Fonte: Elaborada pelas autoras. 
Anexo 2

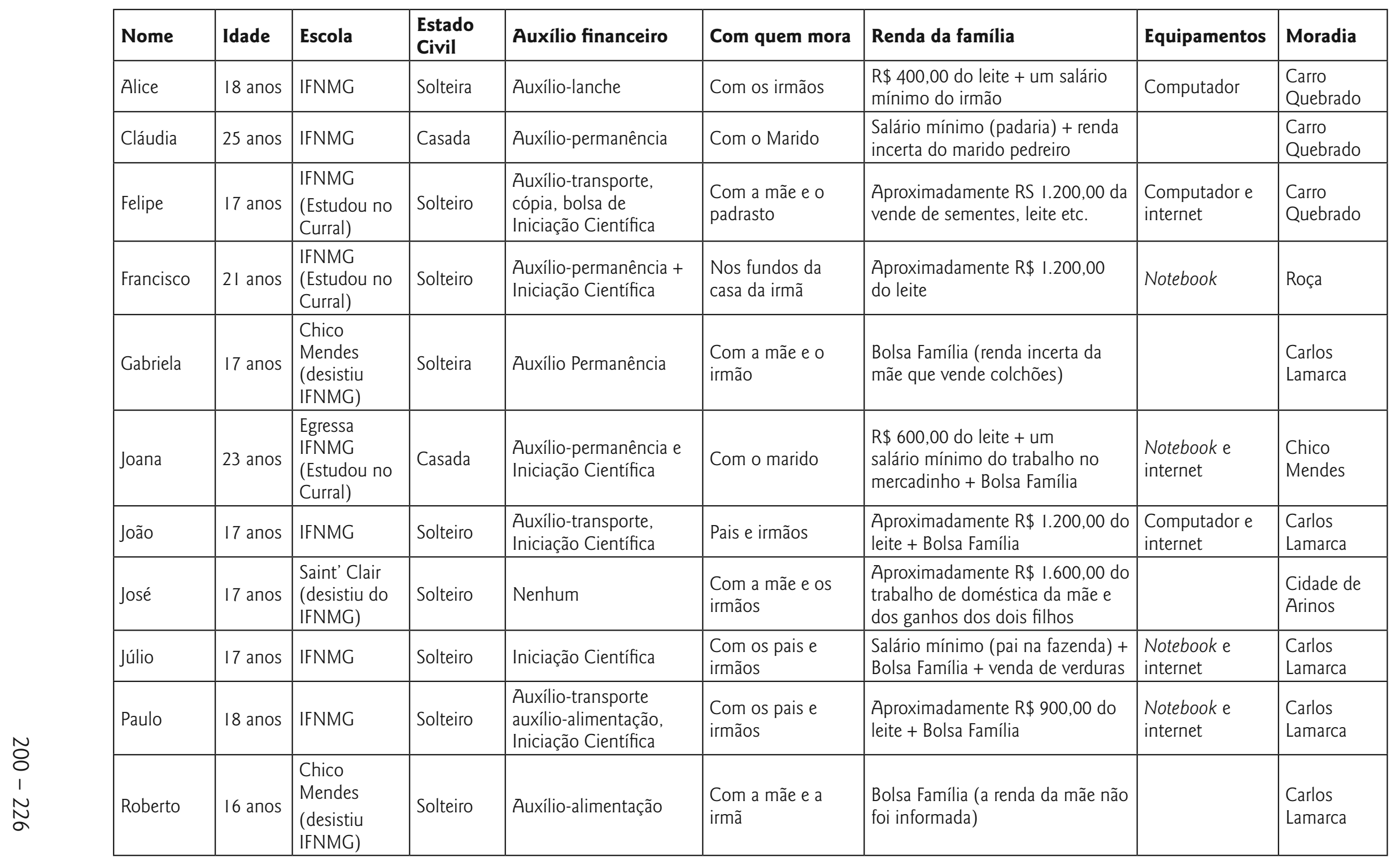




\section{Educational trajectories of young people in agrarian reform settlements in the Citiy of Arinos/MG}

\section{Abstract}

This article discusses the educational trajectories of young people from ten families in agrarian reform settlements in the municipality of Arinos/MG. Situated on the spot settlements surrounding the Federal District, this city was the scene of the struggle for land demonstrations as well as the education of settlers. In the wake of recent studies and starting of the authors Pierre Bourdieu and Bernard Lahire, the goal was to investigate the relationship between family dynamics and school history students researched and families who are served by IFNMG and the State School Chico Mendes. It appears that families build a school perspective for the children while fighting for the right to education. Away from the cultural capital of school success drives devices, parents act releasing the children of domestic work and farm and, also, as well as encouraging further studies. These elements were highlighted in interviews and appearing as motivators of stay or return to studies distinguished from other research on low-income families.

Keywords: Family. School system. Agrarian reform settlements. Cultural capital. 